\title{
IMPLEMENTASI KEBIJAKAN PENGELOLAAN PENGURUS KELOMPOK BELAJAR SKEMA BARU DI UNIVERSITAS TERBUKA
}

\author{
Dwi Kristanti \\ Universitas Terbuka \\ e-mail: dwik@ecampus.ut.ac.id
}

\begin{abstract}
The learning system at the Open University, both abroad and in Indonesia, there is a learning program that really demands student independence. This study aims to analyze the implementation of management policies of the management of the new scheme of study groups at the Open University of UPBJJ-UT Bengkulu and UPBJJ-UT Padang. The number of respondents in this study were 445 Bengkulu students and in Padang. The research data analysis used was the independent sample t-test. The collected data was analyzed using Statistical Package for Social Sciences (SPSS) software version 16.0 for Windows. The results of the first study, show that obtained F-count value 42,808 and sig value. 0,000< 0,005 . Second, the implementation of management policies has a t-count value of 6.872 and a sig value. 0,000<0,005. And finally, the implementation of management policies has a tcount value of 7.404 and a sig value. 0,000 $<0,005$. Based on the results of the study indicate that the two regions still need supervision of the performance of the study group administrators at the Open University. Student satisfaction is considered to be lacking in POKJAR's performance. But in the category often and very often the UT Padang region is bigger than the UT Bengkulu region, this also shows that the oversight is still more than the Bengkulu Open University entity in carrying out its duties and authority as the management of the study group so that service to students is not constrained and students understand Open University procedures.
\end{abstract}

Keywords: Policy Implementation, Pokjar's management

\section{PENDAHULUAN}

Sistem pembelajaran di Universitas Terbuka, baik di luar negeri maupun di Indonesia, ada suatu program pembelajaran yang betul-betul menuntut kemandirian mahasiswa, yaitu program pembelajaran dalam melakukan penelitian untuk penulisan skripsi, tesis, atau disertasi. Seorang mahasiswa yang akan melakukan penelitian untuk penulisan disertasi misalnya, diberi kebebasan dan bahkan dituntut untuk memilih atau menentukan sendiri permasalahan yang akan diteliti, tujuan penelitiannya, serta metodologi penelitiannya (termasuk di dalamnya pemilihan populasi, sampel, instrumen, cara pengumpulan data, cara menganalisis data, dan cara menyusun laporannya). Bahkan dalam batas-batas tertentu mahasiswa juga diberi sedikit kebebasan dalam memilih promotor atau pembimbing, serta pengujinya.

Program belajar mandiri yang diterapkan secara penuh memberi kesempatan kepada siswa/peserta didik untuk ikut berperan dalam menentukan tujuan, memilih isi pelajaran, dan cara mempelajarinya. Bahkan siswa/peserta didik juga diberi kesempatan untuk ikut menentukan cara dan kriteria evaluasinya. Namun dalam praktik tidak seluruh kemandirian itu diterapkan. 
Sejak 1980-an, penyelenggaraan pendidikan/pelatihan jarak jauh tidak lagi hanya terbatas di lingkungan Departemen Pendidikan. Berbagai institusi di luar Departemen Pendidikan telah menyadari potensi atau keunggulan yang dimiliki oleh model pendidikan/pelatihan jarak jauh. Karena itu, berbagai institusi di luar Departemen Pendidikan mulai memanfaatkan pendidikan/pelatihan jarak jauh ini untuk meningkatkan kualitas sumber daya manusia yang berada di dalam jajarannya masingmasing. Kebijakan yang demikian ini semakin mengemuka dan menguat sejak Indonesia dilanda krisis.Sekalipun sudah mulai tampak kemajuan di bidang pendidikan/pelatihan jarak jauh, namun pada kenyataannya, informasi mengenai hal ini sulit diperoleh.Karena sangat terbatasnya informasi yang tersedia, masing-masing institusi cenderung menyelenggarakan pendidikan/pelatihan jarak jauh berdasarkan berbagai keterbatasan yang dimiliki dan yang mampu diperolehnya. Sekalipun sebenarnya telah ada beberapa institusi yang maju atau berkembang pesat di dalam penyelenggaraan pendidikan/pelatihan jarak jauh.

Dengan penerapan metode belajar jarak jauh ini, peserta didik yang telah bekerja akan tetap dapat melaksanakan pekerjaannya dan tidak perlu meninggalkan tempat kerja; dan, di sisi lain secara fleksibel mereka tetap dapat mengikuti program pendidikan/pelatihan jarak jauh yang dibutuhkannya untuk pengembangan kualitas dirinya sesuai dengan ketersediaan waktunya. Interaksi peserta pendidikan/pelatihan jarak jauh dengan narasumber tetap dapat dijalin, yaitu antara lain melalui berbagai fasilitas yang tersedia, seperti fax, telepon, maupun e-mail.

Karakteristik sistem pendidikan jarak jauh yang diterapkan UT menuntut mahasiswa untuk mandiri dan proaktif dalam menempuh studi. Mahasiswa harus memiliki kedisiplinan untuk mengatur waktu belajar, membuat prioritas, mempelajari bahan ajar, mengatasi permasalahan dan kesulitan belajar secara cepat dan mandiri. Dalam upaya memandirikan mahasiswa, UT menyediakan berbagai sumber belajar bagi mahasiswa, seperti bahan ajar cetak, bahan ajar online, dan bahan ajar noncetak, yang didesain untuk belajar mandiri. Proses belajar mahasiswa difasilitasi dengan berbagai jenis bantuan belajar, seperti Tutorial Tatap Muka (TTM), Tutorial Online (Tuton), dan Latihan Mandiri (LM). Layanan administrasi akademik seperti registrasi, pembayaran uang kuliah, pencetakan kartu peserta ujian, serta ujian akhir semester (UAS) juga disediakan secara online.

Kenyataan dilapangan banyak terdapat mahasiswa yang belum mandiri, sehingga mahasiswa UT memerlukan layanan terkoordinir untuk memfasilitasi kegiatan belajar secara berkelompok. Untuk keperluan ini, Pengurus Kelompok Belajar (Pokjar) diperlukan untuk membantu memberikan layanan administrasi dan informasi tentang UT kepada mahasiswa yang memerlukan layanan secara berkelompok. Pokjar dapat berbentuk Pokjar Mandiri atau Pokjar UPBJJUT. Pokjar Mandiri adalah Pokjar yang dibentuk atas inisiatif mahasiswa secara mandiri dan diketuai oleh mahasiswa. Pokjar UPBJJ-UT dibentukoleh UPBJJ-UT untuk membantu memberikan layanan kepada sekelompok mahasiswa dan dikoordinasikan oleh satu orang Pengurus Pokjar.

Pengangkatan Pengurus Pokjar dilaksanakan sesuai prinsip berikut: (1) Azas Manfaat, yakni untuk memperlancar kegiatan kelompok belajar dan komunikasi antara Pokjar dengan UPBJJ-UT; (2) Aksesibilitas Layanan, yakni untuk mendekatkan layanan UT kepada kelompok belajar. Keberadaan Pokjar juga dibentuk untuk lebih meningkatkan layanan kepada mahasiswa; pengurus pokjar skema lama pada umumnya tidak terkait dengan Dinas Pendidikan (perorangan); pengurus pokjar rata-rata sudah dan akan memasuki masa pensiun; Peraturan \& Undang-Undang Sistem pemerintahan (SABER PUNGLI) dan untuk memperbaiki respon dan hubungan baik dengan Kepala Dinas Pendidikan/Unsur Muspida, Sekolah tempat TTM/Praktik/Praktikum, UAS yang terus diperbaiki. Skema tutorial yang mengharuskan konsistensi \& kesetabilan pengelompokan mahasiswa di lapangan termasuk memelihara kesetabilan mahasiswa melakukan pembayaran SPP. Keberadaan 
Pokjar yang demikian perlu mendapatkan perhatian dari Universitas Terbuka. Baik dan tidaknya Pokjar akan berpengaruh terhadap persepsi masyarakat tentang cita positif Universitas Terbuka. Sehingga hal yang menarik melakukan penelitian tentang implementasi kebijakan pengelolaan pengurus kelompok belajar skema baru di Universitas Terbuka dengan mengambil wilayah cakupan studi penelitian yaitu UPBJJ-UT Bengkulu dan UPBJJ-UT Padang, dengan keterjangkauan akses yang dimiliki oleh peneliti.

\section{Rumusan Masalah}

Berdasarkan latar belakang yang telah dijabarkan, maka rumusan masalah penelitian ini: Bagaimana implementasi kebijakan pengelolaan pengurus kelompok belajar skema barudi Universitas Terbuka yaitu UPBJJ-UT Bengkulu dan UPBJJ-UT Padang?

\section{Tujuan}

Dalam hasil penelitian ini akan menganalisis implementasi kebijakan pengelolaan pengurus kelompok belajar skema baru di Universitas TerbukaUPBJJ-UT Bengkulu dan UPBJJ-UT Padang.

\section{Manfaat}

1. Secara teoretis penelitian ini diharapkan dapat memberikan kontribusi bagi Universitas Terbuka dalam pengelolaan pengurus kelompok belajar skema baru disetiap wilayah atau provinsi.

2. Secara praktis, penelitian ini dapat memberikan sumbangan bahan pemikiran Bagi dunia pendidikan dalam penyelenggaraan pendidikan jarak jauh khususnya di UPBJJ-UT Bengkulu dan UPBJJ-UT Padang.

3. Sebagai referensi peneliti lain untuk melakukan penelitian sejenis agar lebih mendalam.

\section{Kerangka Teori}

\section{Sistem Pembelajaran di Universitas Terbuka dan Pengurus Kelompok Belajar}

Universitas Terbuka diresmikan pada tanggal 4 September 1984, berdasarkan Keputusan

Presiden RI No. 41 Tahun 1984. UT telah memperoleh Sertifikat Kualitas dan Akreditasi Internasional dari Internasional Council for Open and Distance Education (ICDE) Mahasiswa UT diharapkan dapat belajar secara mandiri. Universitas Terbuka adalah perguruan tinggi negeri yang menerapkan sistem belajar jarak jauh dan memberikan kesempatan seluas-luasnya untuk memperoleh pendidikan tinggi kepada mereka yang karena sesuatu hal tidak dapat mengikuti pendidikan tinggi tatap muka (konvensional). Universitas Terbuka atau biasa disingkat dengan sebutan UT diharapkan mampu menjangkau seluruh pelosok tanah air, tanpa membatasi usia, kondisi sosial ekonomi, dan waktu. Hal penting yang harus dimiliki mahasiswa UT adalah kemandirian dan motivasi untuk maju dan berkembang.

Tujuan pendirian Universitas Terbuka memberikan kesempatan yang luas bagi warga negara Indonesia dan warga negara asing, di mana pun tempat tinggalnya untuk memperoleh pendidikan tinggi.Mengembangkan pelayanan pendidikan tinggi bagi mereka, yang karena bekerja atau karena alasan lain, tidak dapat melanjutkan belajar di perguruan tinggi tatap muka. Mengembangkan program pendidikan akademik dan profesional yang disesuaikan dengan kebutuhan nyata pembangunan, yang belum banyak dikembangkan oleh perguruan tinggi lain.

Pokjar adalah kumpulan mahasiswa UT yang membangun komitmen dan kesepakatan bersama untuk saling membantu dan saling mendukung kelancaran dan keberhasilan belajar di UT dengan atau tanpa fasilitas pihak lain. 


\section{Kewajiban Pengurus Pokjar:}

1. Menjaga citra positif UT.

2. Mempelajari sistem penyelenggaraan pendidikan UT dan ketentuan lain yangterkait dengan layanan belajar mahasiswa.

3. Memberikan informasi tentang potensi calon mahasiswa UT di wilayah kerja masing-masing.

4. Membantu sosialisasi dan promosi tentang program-program pendidikan UT.

5. Membantu calon mahasiswa/mahasiswa dalam melakukan proses registrasi:

a. memastikankelengkapandokumenuntuk administrasi registrasi;

b. menyampaikanberkasregistrasicalonmahasiswa/mahasiswa ke UPBJJ-UT;

c. menerima dan memeriksa Lembar Data Pribadi (DP) calon mahasiswa dan LIP calon/mahasiswa;

d. membantu calon/mahasiswa melakukan pembayaran SPP;

e. membantumahasiswa melakukanperubahan DP.

f. Membantu UPBJJ-UT dalam pemberian layanan bantuan belajar mahasiswa dalam bentuk:

a. pendistribusian bahan ajar;

b. pemberian masukan untuk tempat pelaksanaan TTM, praktik, dan praktikum sesuai dengan standar Simintas UT;

c. pengoordinasian pelaksanaan TTM di lokasi tutorial;

d. penyampaian laporan tentang keterlaksanaan TTM/praktik/praktikum sesuai format laporan;

e. pengoordinasian penyelesaian kasus/masalah studi mahasiswa.

7. Membantu UPBJJ-UT menyebarluaskan informasi yang relevan kepada mahasiswa.

8. Membangun komunikasi, interaksi, dan kerja sama yang positif dengan UPBJJ-UT, mahasiswa, tutor, supervisor, dan Pengurus Pokjar lain dalam penyelenggaraan layanan bantuan belajar.

9. Membantu mengoordinasikan keikutsertaan mahasiswa dalam pelaksanaan kegiatan kemahasiswaan, OSMB, UPI, dan kegiatan UT lainnya.

10. Membantu mempersiapkan mahasiswa untuk mengikuti ujian yang meliputi:

a. membagikan Kartu Tanda Peserta Ujian (KTPU) kepada setiap mahasiswa dalam kepengurusan kelompok belajarnya.

b. membantu mengarahkan mahasiswa mengikuti ujian sesuai jadwal.

c. membantu menyelesaikan permasalahan mahasiswa terkait ujian

11. Membuat laporan Pengurus Pokjar per semester kepada UPBJJ-UT.

Dengan demikian peran dan fungsi dari pengelola kelompok belajar dalam tercapainya sistem pembelajaran yang mandiri sesuai dengan ketentuan sistem pelayanan jarak jauh di Universitas Terbuka akan bersinergi bila dalam hal ini dapat diimplementasikan bersama dengan berbagai pihak yang mendukung dan ikutserta menciptakan atmosfir sistem pembelajaran yang mandiri.

\section{Implementasi Kebijakan}

Implementasi dalam kamus besar bahasa Indonesia berarti pelaksanaan atau penerapan (Poerwadarminta, 1990). Istilah implementasi biasanya dikaitkan dengan suatu kegiatan yang dilaksanakan untuk mencapai tujuan tertentu. Kamus Webster, merumuskan secara pendek bahwa to implement (mengimplementasikan) berarti to provide the means for carryingout (menyediakan sarana untuk melaksanakan sesuatu), to give practical effect to (menimbulkan dampak atau akibat 
terhadap sesuatau). Pengertian tersebut mempunyai arti bahwa untuk mengimplementasikan sesuatu harus disertai sarana yang mendukung yang nantinya akan menimbulkan dampak atau akibat terhadap sesuatu itu. (Abdul Wahab,2004). Van Meter dan Van Hom (dalam Abdul Wahab 1997), menyatakan bahwa: Proses implementasi adalah "those achivemen by public or private individuals groups that are directed the achievement of objecteves set forth in prior decision" (tindakan-tindakan yang dilakukan oleh individu-individu atau pejabat-pejabat atau kelompokkelompokpemerintah atau swasta yang diarahkan pada tercapainya tujuan-tujuan yang telah digariskan dalam keputusan kebijaksanaan). Implementasi kebijakan merupakan suatu upaya suatu upaya untuk mencapai tujuan-tujuan tertentu dengan saran-sarana tertentu dan dalam urutan waktu tertentu (Sunggono, 1994).

Implemetasi suatu kebijakan dibedakan menjadi dua, yaitu: indikator output dan indikator outcome. Indikator output digunakan untuk mengetahui konsekuensi langsung yang dirasakan oleh kelompok sasaran sebagai akibat adanya realisasi kegiatan, aktivitas, pendistribusian hibah, subsidi dan lain-lain. Implementasi kebijakan pada prinsipnya adalah cara agar sebuah kebijakan dapat mencapai tujuannya. Di dalam Winarno (2002) Implementasi kebijakan dipandang dalam pengertian yang luas, merupakan alat administrasi hukum dimana berbagai aktor, organisasi, prosedur, dan teknik yang bekerja bersama-sama

Menurut pandangan Edward III, implementasi kebijakan dipengaruhi oleh empat variabel yang saling berhubungan satu sama lain, yaitu struktur birokrasi, sumber daya, komunikasi, dan disposisi (Edward III, 1980). Berikut penjelasan masing-masing variabel tersebut:

1. Struktur organisasi; Struktur organisasi yang bertugas mengimplementasikan kebijakan mempunyai pengaruh yang penting dalam proses implementasi.

2. Sumber daya; Sumber daya merupakan faktor yang penting agar implementasi kebijakan dapat berjalan efektif. Sumber daya dapat berwujud sumber daya manusia, yaitu implementor yang kompeten.

3. Komunikasi; Keberhasilan implementasi kebijakan mensyaratkan agar implementor mengetahui apa yang harus dilakukan. Apa yang menjadi tujuan dan sasaran kebijakan harus ditransmisikan kepada kelompok sasaran (target groups) sehingga dapat mengurangi distorsi implementasi. Apabila tujuan dan sasaran suatu kebijakan tidak jelas atau bahkan tidak diketahui sama sekali oleh kelompok sasaran, maka kemungkinan akan terjadi resistensi dari kelompok sasaran.

4. Disposisi; Disposisi adalah watak dan karakteristik yang dimiliki oleh implementor, seperti komitmen, kejujuran, sifat demokratis. Apabila implementor memiliki disposisi yang baik, maka dia akan menjalankan kebijakan dengan baik seperti apa yang diinginkan oleh pembuat kebijakan. Ketika implementor memiliki sikap atau perspektif yang berbeda dengan pembuat kebijakan, maka proses implementasi kebijakan menjadi tidak efektif.

\section{METODE \\ Pendekatan}

Penelitian ini juga menggunakan pendekatan kuantitatif. Penelitian yang akan dilakukan ini menggunakan pendekatan kuantitatif untuk melihat pengaruh antar fenomena (Creswell, 2009). Pendekatan ini akan menggunakan prosedur statistik (Zikmund et al., 2008). Penelitian kuantitatif umumnya ditujukan untuk membuat generalisasi dari hasil analisis, dan penelitiannya dapat direplikasi (Creswell, 2009; Sekaran, 2010). Data yang dikumpulkan dengan pendekatan ini dilakukan melalui metode survei. 


\section{Lokasi dan Waktu}

Lokasi penelitian bertempat di UPBJJ-UT Bengkulu dan Padang. Waktu penelitian Mei s.d. Desember 2018. Merupakan unit program belajar jarak jauh yang melaksanakan pengelolaan pengurus kelompok belajar skema baru.

\section{Informan Penelitian}

Informan penelitian ini adalah mahasiswa yang dikelola melalui program (POKJAR) kelompok belajar skema baru yang ada di UPBJJ-UT Padang dan Bengkulu.

\section{Metode Pengambilan Sampel}

Pada penelitian ini, populasi yang digunakan adalah mahasiswa UPBJJ-UT Bengkulu dan UPBJJ-UT Padang. Populasi juga dimaknai sebagai sekelompok orang, kejadian atau segala sesuatu yang mempunyai karakteristik tertentu (Supranto, 2010; Sekaran, 2010). Zikmund (2010) menjelaskan bahwa populasi sebagai suatu himpunan individu dengan sifat-sifat ditentukan atau dipilih oleh peneliti, sehingga dapat dinyatakan dengan tepat. Selanjutnya, Sampel adalah bagian terkecil dari populasi (Kuncoro, 2003).

Tabel 1. Populasi Penelitian pada UPBJJ-UT Bengkulu dan UPBJJ-UT Padang

\begin{tabular}{lcc}
\hline & Nama UPBJJ-UT & Jumlah Mahasiswa \\
\hline UPBJJ-UT Bengkulu & & 897 \\
UPBJJ-UT Padang & & 1.552 \\
\hline & Total Mahasiswa & 2.449 \\
\hline
\end{tabular}

\section{Data Penelitian diolah: September 2018}

Cara pengambilan sampel pada penelitian ini menggunakan metode random sampling, yaitu mahasiswa/i terbanyak yang dominan di kabupaten/kota di provinsi masing-masing. Setiap unsur populasi memiliki kesempatan sama untuk bisa dipilih menjadi sampel. Untuk menentukan ukuran sampel digunakan rumus Slovin (Consuelo, et al., 2007), yaitu

$$
n=\frac{N}{1+N \cdot(e)^{2}}
$$

Keterangan:

$\mathrm{n}=$ ukuran sampel

$\mathrm{N}=$ ukuran populasi

$\mathrm{E}=$ Tingkat kesalahan yang ditoleransi $(5 \%)$

Bila jumlah populasi mahasiswa UPBJJ-UT Bengkulu dan Padang di masukkan kedalam perhitungan rumus Slovin, maka didapatkan jumlah sampel sebagai berikut:

$$
\begin{aligned}
& n=\frac{N}{1+N \cdot(e)^{2}} \\
& n=\frac{2449}{1+2449 \cdot(0,05)^{2}} \\
& n=\frac{2449}{5,5} \\
& n=445 \text { orang }
\end{aligned}
$$


Teknik menentukan sampel pada tiap UPBJJ-UTBengkulu dan Padang menggunakan proportionate stratified random sampling. Menurut Sugiyono (2008) adalah teknik yang digunakan bila populasi mempunyai anggota/unsur yang tidak homogen dan berstrata secara proporsional.

$$
\text { jumlah sampel tiap UPBJJ -UT }=\frac{\text { Jumlah sampel }}{\text { Jumlah populasi }} \times \text { Jumlah tiap mahasiswa }
$$

Tabel 2. Penentuan Sampel pada Tiap-Tiap UPBJJ-UT

\begin{tabular}{llc}
\multicolumn{1}{c}{ Nama UPBJJ-UT } & Perhitungan & Jumlah Mahasiswa \\
\hline UPBJJ-UT Bengkulu & $\frac{445}{2449} \times 897$ & 163 \\
UPBJJ-UT Padang & $\frac{445}{2449} \times 1552$ & 282 \\
\hline & & 445 \\
\hline
\end{tabular}

Data Penentuan Sampel diolah, Juli 2018.

\section{Pengujian Intrumen}

Pengujian instrumen penelitian digunakan beberapa cara, yaitu uji validitas dan reliabilitas dimana pengujian ini dimaksudkan untuk menunjukkan kesahihan dan konsistensi suatu instrument penelitian. Agar kuesioner yang digunakan merupakan pengukuran yang tepat dalam penelitian ini, maka peneliti akan mengukur validitas dan reliabilitas.

\section{Pengujian Validitas}

Untuk mendapatkan instrumen yang valid maka dilakukan uji validitas. Menurut Sugiyono (2013), alat ukur dikatakan valid apabila alat ukur tersebut dapat mengukur obyek yang seharusnya diukur. Sekaran (2010) Instrumen dikatakan valid berarti menunjukkan alat ukur yang dipergunakan untuk mendapatkan data tersebut valid atau dapat digunakan untuk mengukur apa yang seharusnya diukur. Content validity untuk memastikan bahwa pengukuran memasukkan sekumpulan item yang memadai dan mewakili yang mengungkap konsep. Criterion-related validity terpenuhi jika pengukuran membedakan individu menurut suatu kriteria yang diharapkan diprediksi; dan Construct validity, yaitu uji validitas yang menunjukkan seberapa baik hasil yang diperoleh dari penggunaan ukuran cocok dengan teori yang mendasari desain tes.

Berdasarkan jenis-jenis validitas tersebut, maka dalam penelitian ini akan digunakan construct validity. Validitas konstruk ada dua jenis, yaitu validasi konvergen dan diskriminan. Menurut Sekaran (2010), validitas konvergen adalah cara mengukur skor dengan dua instrumen yang berbeda dalam mengukur konsep yang sama menunjukkan korelasi yang tinggi, sedangkan validitas diskriminan merupakan cara mengukur skor dua variabel diprediksi tidak berkorelasi dan skor yang diperoleh dengan mengukurnya benar-benar secara pembuktian empiris.

Korelasi antar item pernyataan diuji dengan menggunakan faktor analisis. Faktor analisis adalah jenis analisis yang digunakan untuk mengenali dimensi-dimensi pokok atau keteraturan dari sebuah fenomena, utamanya digunakan untuk mereduksi data atau meringkas (Supranto, 2010). 
Instrumen dikatakan valid jika nilai korelasi $(r)>0,3$ untuk validitas konvergen dan nilai korelasi $(r) \leq$ 0,3 disebut validitas diskriminan (Allen \& Bennet, 2010).

\section{Analisis Reliabilitas}

Reliabilitas adalah indeks yang menunjukkan sejauh mana suatu alat ukur dapat dipercaya atau dapat diandalkan. Instrumen yang realiabel adalah instrumen yang bila digunakan beberapa kali untuk mengukur obyek yang sama akan menghasilkan data yang sama (Sugiyono, 2013). Reliabilitas adalah ukuran yang menunjukkan bahwa alat ukur yang digunakan dalam penelitian mempunyai keandalan sebagai alat ukur, diantaranya di ukur melalui konsistensi hasil pengukuran dari waktu ke waktu jika fenomena yang diukur tidak berubah (Sekaran, 2010). Uji reliabilitas berguna untuk menetapkan apakah instrumen yang dalam hal ini kuesioner dapat digunakan lebih dari satu kali, paling tidak oleh responden yang sama akan menghasilkan data yang konsisten.

Dalam mengukur reliabilitas, penelitian ini menggunakan koefisien alpha yang dikembangkan oleh Cronbach. Koefisien alpha ini adalah yang paling sering digunakan dalam penelitian ilmu sosial karena ketelitian pengukurannya yaitu dengan cara item-itemnya menganalisis. Instrumen dikatakan reliabel jika mempunyai koefisien alpha lebih besar atau sama dengan $0,5(\geq 0,5)$ untuk penelitian awal (Thorndike \& Hagen, 1997), karena mengikuti kaidah umum dalam perhitungan alpha dengan menggunakan software SPSS yang tidak menampilkan nilai probabilitas, maka penelitian ini mengikuti saran dari Thorndike dan Hagen.

\section{Analisis Data}

Penelitian ini adalah penelitian kuantitatif dengan metode survei. Data yang telah dikumpulkan melalui penyebaran kuesioner akan dianalisis berdasarkan pada permasalahan penelitian yang dikemukakan pada sub bagian sebelumnya.

a. Analisis Deskriptif

Analisis ini digunakan untuk mengkaji implementasi kebijakan pengelolaan pengurus kelompok belajar skema baru di Universitas Terbuka yaitu UPBJJ-UT Bengkulu dan UPBJJ-UT Padang. Analisis deskriptif yaitu analisis non-statistik yang hanya berupa uraian terhadap persepsi variabel penelitian yang digambarkan sesuai dengan kondisi dan realita di lapangan (Singarimbun \& Effendi, 2006).

Teknik analisis data statistik deskriptif penyajian data melalui mean. Tujuan ananlisis statistik mean ini untuk memberikan gambaran mengenai data-data yang didapat dari angket yang bersifat menggambarkan karakteristik tertentu dari responden dan mengklasifikasikan nilai kategorisasi ratarata.

Penilaian persepsi responden terhadap item pernyataan menggunakan skala Likert jenjang 5. Skala Likert menurut Sugiyono (2013) digunakan sebagai acuan untuk menentukan kelas interval hasil penelitian. Sebagai pedoman kelas atas pernyataan responden terhadap variabel penelitian dengan penentuan rata-rata keseluruhan sebagai berikut:

Nilai tertinggi adalah 5,00 dan nilai terendah adalah 1,00 Interval kelas adalah $(5-1) / 5=0,80$ sehingga didapat kelas rata-rata yaitu:

1,00-1,80 : Tidak pernah

$1,81-2,60$ : Sangat jarang

$2,61-3,40$ : Kadang-kadang 
$3,41-4,20$ : Sering

$4,21-5,00$ : Sangat sering

b. Statistik Inferensial

Variabel independen kualitatif dalam penelitian ini memiliki dua kategori. Oleh sebab itu, dilakukan pengujian dengan metode uji beda,yaitu perbedaan antara kelompok 1 dengan kelompok lainnya (independent sample t- test). Model uji beda ini digunakan untuk menganalisis model penelitian pre-post atau sebelum dan sesudah. Uji beda digunakan untuk mengevaluasi perlakuan (treatment) tertentu pada satu sampel yang sama pada dua periode pengamatan yang berbeda (Pramana \& Nurchayo, 2012). Independent sample t- test digunakan apabila data berdistribusi normal. Menurut Widiyanto (2013), independent sample t-test merupakan salah satu metode pengujian yang digunakan untuk mengkaji keefektifan perlakuan, ditandai adanya perbedaan ratarata sebelum dan rata-rata sesudah diberikan perlakuan. Data yang terkumpul dianalisis dengan menggunakan bantuan software Statistical Package for Social Sciences (SPSS) version 16.0 for windows.

\section{HASIL PENELITIAN DAN PEMBAHASAN \\ Deskripsi Implementasi Kebijakan}

Gambaran tentang implementasi kebijakan pengelolaan pengurus kelompok belajar skema baru di Universitas Terbuka dengan mengambil wilayah cakupan studi penelitian yaitu UPBJJ-UT Bengkulu dan UPBJJ-UT Padang, peneliti mendeskripsikan hasil ini berdasarkan persepsi responden dengan melalui mahasiswa di UPBJJ-UT Bengkulu dan UPBJJ-UT Padang. Berikut ini disajikan mengenai deskriptif jawaban responden terhadap pernyataan implementasi kebijakan.

Tabel 3. Tanggapan Responden Terhadap Pernyataan Implementasi Kebijakan

\begin{tabular}{lccc}
\hline & \multirow{2}{*}{ Kategori } & \multicolumn{2}{c}{ Persentase Mahasiswa UPBJJ } \\
\cline { 3 - 4 } & & Bengkulu & Padang \\
\hline Tidak pernah & 0,97 & 1,41 \\
Sangat jarang & 5,61 & 3,51 \\
Kadang-kadang & 32,99 & 8,93 \\
Sering & 45,37 & 26,37 \\
Sangat sering & & 15,05 & 59,77 \\
\hline \multicolumn{2}{c}{ Total } & 100,00 & 100,00 \\
\hline
\end{tabular}

Sumber: data diolah (2018)

Berdasarkan Tabel 3, untuk tanggapan mahasiswa UPBJJ-UT Bengkulu diketahui bahwa sebanyak 32,99\% menyatakan kadang-kadang, 45,37\% responden menyatakan sering dan 15,05\% menyatakan sangat sering. Hasil tanggapan tersebut menyimpulkan implementasi kebijakan tersebut sudah berjalan dengan baik tetapi kita tidak boleh tutup mata bahwa masih ada sebanyak 0,97 dan 5,61 menyatakan bahwa tidak pernah dan sangat jarang pengurus kelompok kerja melakukan tugasnya dengan baik.

Sedangkan tanggapan mahasiswa UPBJJ-UT Padang diketahui bahwa sebanyak 59,77\% mayoritas menjawab sangat sering dan $26,37 \%$ menyatakan sering. Hasil ini menyatakan bahwa mahasiswa berpendapat bahwa pengurus kelompok kerja pada Provinsi Padang sudah menjalankan tugas dan kinerjanya yang cukup baik lebih dari 50\% lebih mahasiswa menyatakan sering. Tetapi 
begitu juga pada kategori tidak pernah sebesar 1,41 dan 3,51 menyatakan sangat jarang hal ini Provinsi Padang juga masih butuh pengawasan yang lebih terhadap pengurus kelompok belajar.

Setelah diketahui tanggapan responden terhadap pernyataan implementasi kebijakan. Analisis menggunakan perhitungan mean. Perhitungan mean dimaksudkan untuk melihat rata-rata penilaian para responden pada setiap UPBJJ Bengkulu dan Padang. Hasil perhitungan skor mean disajikan pada Tabel 4.

Tabel 4. Rekapitulasi Rata-rata Skor Tanggapan Responden Terhadap Implementasi Kebijakan Pengelolaan

\begin{tabular}{lcc}
\hline \multicolumn{1}{c}{ Variabel } & Skor & Kean \\
& 3,79 & Kriteria \\
\hline Implementasi Kebijakan Pengelolaan UT Bengkulu & 4,28 & $\begin{array}{c}\text { Sangat } \\
\text { baik }\end{array}$ \\
\hline
\end{tabular}

Sumber: data diolah (2018)

$$
\begin{array}{ll}
1,00-1,80 & : \text { Tidak baik } \\
1,81-2,60: & \text { Sangat tidak baik } \\
2,61-3,40: & \text { Cukup } \\
3,41-4,20: & \text { Baik } \\
4,21-5,00: & \text { Sangat Baik }
\end{array}
$$

Berdasarkan hasil perhitungan mean pada Tabel 4, dapat diketahui bahwa implementasi kebijakan pengelolaan UT Padang memiliki mean paling tinggi yaitu sebesar 4,28 dikatakan sangat baik karena nilai rentang terdapat antara $4,21-5,00$. Hal ini menunjukkan bahwa implementasi kebijakan pengelolaan UT di Padang lebih baik dari Provinsi Bengkulu hal ini dikarenakan Pengurus kelompok kerja Provinsi Padang menjalankan tugas dan wewenangnya sesuai dengan standar Universitas Terbuka yaitu dapat melayani mahasiswa dalam melakukan administrasi dan menyampaikan informasi yang relevan kepada mahasiswa.

Sedangkan implementasi kebijakan pengelolaan UT Bengkulu memiliki mean dengan skor 3,79 dinyatakan baik karena nilai rentang terdapat antara 3,41-4,20. Hal ini menunjukkan bahwa implementasi kebijakan pengelolaan UT di Bengkulu masih butuh pengawasan hal ini mungkin Universitas Terbuka Bengkulu belum sepenuhnya melakukan pengawasan terhadap kinerja pengurus kelompok belajar yang ada di Kabupaten Kota yang ada di Provinsi Bengkulu.

\section{Uji Kualitas Data}

Uji kualitas data dilakukan untuk memastikan apakah instrumen kuesioner yang digunakan memang sudah memenuhi syarat validitas dan realiabilitas.

\section{Uji Validitas}

Pengujian kualitas data yang digunakan untuk mengukur tingkat validitas data adalah dengan koefisien korelasi menggunakan bantuan software Statistical Package for Social Sciences (SPSS) version 16.0 for windows. Proses perhitungan akan dilakukan dengan menggunakan program SPSS 16.0 kemudian nilai $r$ hitung yang diperoleh dibandingkan dengan nilai korelasi $(r) \leq$ 
0,3 dalam pengujian validitas kuesioner dikatakan valid apabila $r$ hitung lebih besar dari $r$ tabel sesuai (Allen \& Bennet, 2010). Hasil pengujian validitas instrumen penelitian dapat dilihat pada Tabel 5.

Tabel 5. Hasil Vadilitas Koefisien Korelasi Implementasi Kebijakan Pengelolaan

\begin{tabular}{|c|c|c|c|}
\hline \multirow{2}{*}{ Indikator/Pernyataan } & \multicolumn{2}{|c|}{ Mahasiswa UPBJJ } & \multirow{2}{*}{ Keterangan } \\
\hline & Bengkulu & Padang & \\
\hline Menjaga citra positif & 0,572 & 0,512 & Valid \\
\hline $\begin{array}{l}\text { Menguasai sistem penyelenggaraan pendidikan dan } \\
\text { ketentuan terkait dengan pelayanan }\end{array}$ & 0,448 & 0,410 & Valid \\
\hline Informasi tetang potensi calon mahasiswa & 0,736 & 0,483 & Valid \\
\hline Sosialisasi dan promosi tentang program pendidikan & 0,766 & 0,405 & Valid \\
\hline $\begin{array}{l}\text { a. Memastikan kelengkapan dokumen untuk administrasi } \\
\text { registrasi }\end{array}$ & 0,710 & 0,453 & Valid \\
\hline b. Menyampaikan berkas registrasi calon mahasiswa & 0,688 & 0,298 & Valid \\
\hline $\begin{array}{l}\text { c. Menerima dan memeriksa lembar data pribadi dan } \\
\text { mahasiswa }\end{array}$ & 0,662 & 0,445 & Valid \\
\hline d. Membantu mahasiswa melakukan pembayaran SPP & 0,573 & 0,582 & Valid \\
\hline e. Membantu mahasiswa melakukan perubahan DP & 0,578 & 0,589 & Valid \\
\hline a. Pendistribusian bahan ajar & 0,560 & 0,707 & Valid \\
\hline $\begin{array}{l}\text { b. Pemberian masukan tutorial tatap muka, pratik dan } \\
\text { praktikum }\end{array}$ & 0,630 & 0,660 & Valid \\
\hline c. Koordinasi pelaksanaan tutorial dilokasi & 0,635 & 0,699 & Valid \\
\hline d. Penyampaian laporan tutorial/praktik/praktikum & 0,614 & 0,668 & Valid \\
\hline e. Koordinasi penyelesaian kasus/masalah mahasiswa & 0,730 & 0,569 & Valid \\
\hline Diseminasi informasi yang relevan & 0,733 & 0,530 & Valid \\
\hline $\begin{array}{l}\text { Membangun komunikasi, interaksi dan kerjasama yang } \\
\text { positif }\end{array}$ & 0,678 & 0,672 & Valid \\
\hline $\begin{array}{l}\text { Koodinasi keikutsertaan mahasiswa dalam pelaksanaan } \\
\text { kegiatan }\end{array}$ & 0,624 & 0,605 & Valid \\
\hline Membuat laporan pengelolaan pokjar persemester & 0,575 & 0,540 & Valid \\
\hline
\end{tabular}

Sumber: data diolah (2018)

Berdasarkan hasil analisis, nilai korelasi dalam uji validitas item (butir) pada penelitian ini, berkisar antara 0,410 sampai dengan 0,766. Menurut Allen \& Bennet (2010), nilai r hitung yang diperoleh dibandingkan dengan nilai korelasi (r) 0,3 dalam pengujian validitas kuesioner dikatakan valid apabila r hitung lebih besar dari $r$ tabel sesuai, maka instrumen tersebut sudah valid. Berdasarkan tabel diatas diketahui bahwa seluruh nilai koefisien korelasi indikator penelitian lebih besar dari nilai r-tabel 0,410 sampai dengan 0,766(r-hitung > r-tabel). Dengan demikian peneliti dapat menyimpulkan bahwa seluruh indikator penelitian dinyatakan valid. 


\section{Uji Reliabilitas}

Instrumen dikatakan reliabel jika mempunyai koefisien alpha lebih besar atau sama dengan $0,5(\geq 0,5)$ untuk penelitian awal (Thorndike \& Hagen, 1997), karena mengikuti kaidah umum dalam perhitungan alpha dengan menggunakan software SPSS yang tidak menampilkan nilai probabilitas, maka penelitian ini mengikuti saran dari Thorndike dan Hagen. Hasil pengujian reliabilitas instrumen penelitian dapat dilihat pada Tabel 6 .

Tabel 6. Hasil ReliabilitasKoefisien Korelasi Implementasi Kebijakan Pengelolaan

\begin{tabular}{lcl}
\hline \multicolumn{1}{c}{ Variabel } & Koefisien & Kriteria \\
\hline Implementasi Kebijakan Pengelolaan UT Bengkulu & a & Reliabel \\
Implementasi Kebijakan Pengelolaan UT Padang & 0,897 & Reliabel \\
\hline
\end{tabular}

Sumber: data diolah (2018)

Berdasarkan dari Tabel 6 hasil instrumen penelitian dikatakan mempunyai tingkat reliabilitas yang tinggi jika nilai Alpha lebih besar dari 0,6 berdasarkan peneliti terdahulu Mauludin (Thorndike \& Hagen, 1997). Hal ini menunjukkan bahwa semua pernyataan tentang motivasi, kemampuan dan kinerja yang digunakan dalam penelitian ini reliabel.

\section{Hasil Pengujian Data \& Pembahasan}

Pembahasan dalam sub-sub ini adalah menganalisis implementasi kebijakan pengelolaan pengurus kelompok belajar skema baru di Universitas Terbuka UPBJJ-UT Bengkulu dan UPBJJ-UT Padang. Oleh sebab itu, dilakukan pengujian dengan metode uji beda rata-rata untuk dua sampel berpasangan (paired sample t-test) menggunakan bantuan software Statistical Package for Social Sciences (SPSS) version 16.0 for windows. Hasil pengujiian dapat dilihat pada Tabel 7.

Tabel 7. Hasil Analisis Uji Independent Samples T-Test Terhadap Implementasi

Kebijakan

\begin{tabular}{|c|c|c|c|c|c|c|c|}
\hline \multirow{2}{*}{ Variabel } & \multirow{2}{*}{ Kelompok } & \multirow{2}{*}{$\mathrm{N}$} & \multirow{2}{*}{ Mean } & \multicolumn{2}{|c|}{ Levene's test } & \multicolumn{2}{|c|}{ Uji t } \\
\hline & & & & $\mathrm{F}$ & Sig. & $t$ & Sig. \\
\hline \multirow{2}{*}{$\begin{array}{l}\text { Implementasi kebijakan } \\
\text { pengelolaan pengurus kelompok } \\
\text { belajar skema baru }\end{array}$} & $\begin{array}{l}\text { Mahasiswa UT } \\
\text { Bengkulu }\end{array}$ & 163 & 3,79 & \multirow{2}{*}{42,808} & \multirow{2}{*}{0,000} & 6,872 & 0,000 \\
\hline & $\begin{array}{l}\text { Mahasiswa UT } \\
\text { Padang }\end{array}$ & 282 & 4,28 & & & 7,404 & 0,000 \\
\hline
\end{tabular}

Sumber: data diolah (2018)

Berdasarkan Tabel 7 uji independent sample t- test diperoleh nilai F-hitung 42,808 dan nilai sig. 0,000<0,005, maka dapat diasumsikan bahwa implementasi kebijakan pengelolaan pengurus kelompok belajar skema baru diterima dengan sig. 0,000<0,005 hal ini menunjukan bahwa Univeritas Terbuka Bengkulu dan Padang sudah menerapkan kebijakan pengelolaan pengurus kelompok belajar dengan baik.

Selanjutnya, uji independent sample test diperoleh mahasiswa UT Bengkulu tentang implementasi kebijakan pengelolaan terdapat nilai t-hitung 6,872 dan nilai sig. 0,000<0,005, maka dapat disimpulkan bahwa sedangkan,uji independent sample test diperoleh mahasiswa UT Padang tentang implementasi kebijakan pengelolaan terdapat nilai t-hitung 7,404 dan nilai sig. 0,000<0,005, 
maka dapat disimpulkan bahwa impelemtasi kebijakan pengelolaan pengurus kelompok belajar skema baru sudah baik tetapi implementasi kebijakan tersebut Provinsi Padang lebih baik terpaut sedikit yaitu 0,532 daripada Provinsi Bengkulu hal ini menunjukan bahwa Provinsi Bengkulu butuh pengawasan lebih pada pengurus kelompok belajar sehingga mahasiswa mendapatkan pelayanan yang baik.

\section{SIMPULAN DAN SARAN Simpulan}

Berdasarkan hasil penelitian menunjukkan bahwa kedua provinsi masih butuh pengawasan terhadap kinerja pengurus kelompok belajar pada Universitas Terbuka. Data yang terdapat pada hasil penelitian menunjukan bahwa masih ada POKJAR yang belum melakukan kinerjanya secara efektif dan efisien hal ini dapat ditujukan bahwa masih ada mahasiswa yang menjawab tidak pernah dan sangat jarang pada kedua Provinsi tersebut. Kepuasan mahasiswa dianggap masih kurang terhadap kinerja POKJAR tersebut. Tetapi dalam kategori sering dan sangat sering Provinsi Padang lebih besar dari pada Provinsi Bengkulu hal ini juga menunjukan bahwa masih butuhnya pengawasan lebih dari pihak Univertitas Terbuka Bengkulu dalam menjalankan tugas dan wewenangnya sebagai pengurus kelompok belajar agar pelayanan pada mahasiswa tidak terkendala dan mahasiswa mengerti akan prosedur Universitas Terbuka.

\section{Saran}

Berdasarkan hasil penelitian ini, maka saran yang dapat diberikan adalah UPBJJ-UT Bengkulu dan UPBJJ-UT Padang yang terdiri atas unsur pimpinan dan staf UPBJJ-UT agar lebih memperketat proses evaluasi pengurus POKJAR yang diperoleh dari data mahasiswa sebagai pengguna dan staf UPBJJ dalam pelaksanaan monitoring dan evaluasi kegiatan UT di lapangan UPBJJ sebagai pihak yang bermitra.

\section{REFERENSI}

Allen, P. \& Bennett, K. (2010). PASW Statistics by SPSS: S practical guideversion 18.0 (1st ed.).

Australia: Cengage Learning Australia.

Bambang Sunggono.(1994).Hukum dan Kebijaksanaan Publik. Jakarta: PT Karya Unipress.

BKN. (2004). Aplikasi Evaluasi Jabatan Terhadap Keadilan Internal Gaji Pegawai Negeri

Sipil.Jakarta: Badan Kepegawaian Negara.

Consuelo G, Sevilla, et al. (2007). Research Methods. Rex Printing Company. Quezon City.

Creswell, J.W. (2009). Research design: qualitative, quantitative and mixedmethods approaches (3rd ed.). London: Sage.

Edward III, George C. (1980).Implementing Public Policy. Congressional. Quarterly Press. Washington.

Kuncoro, Mudrajat.(2003). Metode Riset untuk Bisnis dan Ekonomi. Jakarta: Erlangga.

Poerwadarminta, W.J.S.(1990). Kamus Besar Bahasa Indonesia. Balai Pustaka. Jakarta.

Pratama, D.A., Pali, M. \& Nurcahyo, F.A. (2012). Pengaruh Kepribadian Berdasarkan The Big Five Personality terhadap Kepuasan Kerja Karyawan Hotel. Jurnal Gema Aktualita, Vol. 1, No. 1, Hal. 57-67.

Sekaran, U. (2010). Research methods for business: A skill building approach. New Jersey: John Willey \& Son.

Singarimbun, M. \& Effendi, S. (2006). Metode Penelitian Survei. Jakarta: LP3ES. 
Sugiyono. (2008).Metode Penelitian Kuantitatif, Kualitatif dan $R \& D$, Alfabeta, Bandung.

Sugiyono. (2013). Metode Penelitian Bisnis, Pendekatan Kuantitatif, Kualitatif dan R \& D. Cetakan Ke Enam Belas. Bandung: Alfabeta.

Supranto, J. (2010). Analisis Multivariat Arti dan Interpretasi. Jakarta: Penerbit Rineka Cipta.

Thorndike R.L. \& Hagen E.P. (1997).Measurement And Evaluation In Psychology And Education. New York: John Wiley and Sons, Inc.

Wahab, Solichin Abdul. (2004). Analisis Kebijaksanaan: Dari Formulasi ke Implementasi Kebijaksanaan Negara. Jakarta: Sinar Grafika.

Widiyanto. (2013). Statistika Terapan. Jakarta: PT Alex Mediaa Komputindo.

Winarno, Budi. (2002). Teori dan Proses Kebijkan Publik. Yogyakarta: Media Pressindo.

Zikmud, W.G. (2010). Business Research Method. Fort Worth: Harcourt Brace Jovanovich College Publishers. 